University of Nebraska - Lincoln

DigitalCommons@University of Nebraska - Lincoln

USDA National Wildlife Research Center - Staff Publications
U.S. Department of Agriculture: Animal and Plant Health Inspection Service

2018

\title{
Trace element concentrations in the small Indian mongoose (Herpestes auropunctatus) from Hawaii, USA
}

\author{
Sawako Horai \\ Tottori University, horais@muses.tottori-u.ac.jp \\ Yusuke Nakashima \\ Tottori University \\ Kanae Nawada \\ Tottori University \\ Izumi Watanabe \\ University of Agriculture and Technology \\ Tatsuya Kunisue \\ Ehime University
}

See next page for additional authors

Follow this and additional works at: https://digitalcommons.unl.edu/icwdm_usdanwrc

Part of the Life Sciences Commons

Horai, Sawako; Nakashima, Yusuke; Nawada, Kanae; Watanabe, Izumi; Kunisue, Tatsuya; Abe, Shintaro; Yamada, Fumio; and Sugihara, Robert, "Trace element concentrations in the small Indian mongoose (Herpestes auropunctatus) from Hawaii, USA" (2018). USDA National Wildlife Research Center - Staff Publications. 2184.

https://digitalcommons.unl.edu/icwdm_usdanwrc/2184

This Article is brought to you for free and open access by the U.S. Department of Agriculture: Animal and Plant Health Inspection Service at DigitalCommons@University of Nebraska - Lincoln. It has been accepted for inclusion in USDA National Wildlife Research Center - Staff Publications by an authorized administrator of DigitalCommons@University of Nebraska - Lincoln. 


\section{Authors}

Sawako Horai, Yusuke Nakashima, Kanae Nawada, Izumi Watanabe, Tatsuya Kunisue, Shintaro Abe, Fumio Yamada, and Robert Sugihara 
Original Articles

\title{
Trace element concentrations in the small Indian mongoose (Herpestes auropunctatus) from Hawaii, USA
}

\author{
Sawako Horai ${ }^{\mathrm{a}, *}$, Yusuke Nakashima ${ }^{\mathrm{a}}$, Kanae Nawada ${ }^{\mathrm{a}}$, Izumi Watanabe ${ }^{\mathrm{b}}$, Tatsuya Kunisue ${ }^{\mathrm{c}}$, \\ Shintaro Abe ${ }^{\mathrm{d}}$, Fumio Yamada ${ }^{\mathrm{e}}$, Robert Sugihara ${ }^{\mathrm{f}}$

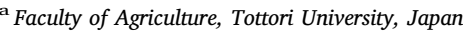 \\ ${ }^{\mathrm{b}}$ Department of Environmental Conservation, Tokyo University of Agriculture and Technology, Japan \\ ${ }^{c}$ Center for Marin Environmental Studies (CMES), Ehime University, Japan \\ ${ }^{\mathrm{d}}$ Naha Nature Conversation Office, Ministry of the Environment, Japan \\ e Forestry and Forest Products Research Institute, Japan \\ ${ }^{\mathrm{f}}$ US Dept. of Agriculture Animal \& Plant Health Inspection Service Wildlife Services, National Wildlife Research Center Hawaii Field Station, USA
}

\section{A R T I C L E I N F O}

\section{Keywords:}

Small Indian mongoose

Trace elements

$\mathrm{Pb}$ toxicity

Firing range

Brain

Biomonitoring

\begin{abstract}
A B S T R A C T
Concentrations of 26 trace elements including essential (Mg, Ca, Cr, V, Mn, Fe, Co, Ni, Cu, Zn, Se, Sr and Mo) and toxic (As, $\mathrm{Cd}$ and $\mathrm{Pb}$ ), were determined in the liver, kidney, brain, hair, muscle, and stomach contents of the small Indian mongooses inhabiting eight areas on three Hawaiian Islands, Oahu, Maui and Hawaii. There were significant differences in concentrations of some metals among the habitats. Cadmium concentrations in mongooses from the macadamia nut orchards on Island of Hawaii were relatively higher than those in populations from other seven areas. Lead concentrations in mongooses from the Ukumehame firing range were significantly higher than those from other areas. Compared to data reported in mongooses from other countries, $\mathrm{Pb}$ concentrations in the brain were higher in the animals from Hawaiian islands, but almost similar levels were observed in the liver and kidney. Intriguingly, brain concentrations of $\mathrm{Pb}$ in three specimens from the Ukumehame firing range exceeded $3.79 \mu \mathrm{g} \mathrm{g}^{-1} \mathrm{WW}$, which was the mean cerebral $\mathrm{Pb}$ level in rats that caused some toxic symptoms after administration in the previous study. Furthermore, two fetuses exhibited higher brain $\mathrm{Pb}$ concentrations than each of their dams. These results prompted us to consider the potential exposure and health effects of $\mathrm{Pb}$ derived from firing range operations on the small Indian mongoose and other animal species including human.
\end{abstract}

\section{Introduction}

The small Indian mongoose (Herpestes auropunctatus) belongs to the order Carnivora in the family Herpestidae (15 genera, 34 species), and its original habitats are Iran, Iraq, Afghanistan, Pakistan, India, Nepal, Bhutan, Bangladesh, Myanmar, southern China, and Hainan Island (Gilchrist et al., 2009). This species has been introduced to at least 76 islands and areas such as Cuba, Jamaica, Puerto Rico, Hawaii, Okinawa, Mauritius, Guiana, Croatia, etc. to reduce crop depredation by field rodents and reduce incidence of snake bites in humans (Barun et al., 2011). Jamaica was the first area where this species was introduced in 1872 and the habitat of this species has expanded globally since then. Additionally, these introduced individuals have caused some negative impacts on crop damage, extinction of endemic species, and hosts of zoonotic diseases hazardous to humans in their introduced areas. The introduction of the small Indian mongoose as a biocontrol technique in these areas has been concluded as a "failure". This species has been designated as one of " 100 of the World's Worst Invasive Alien Species" by the International Union for Conservation of Nature (IUCN) (Lowe et al., 2000).

In Japan, the small Indian mongoose was introduced to two islands, Okinawa and Amamioshima in 1910 and 1979, respectively (Yamada et al., 2015). Some endemic rare species decreased considerably because of predation by this species, and hence an extermination project started in 2005 (Fukasawa et al., 2013). The Javan mongoose (Herpestes javanicus) in Horai et al. (2006) was identified as the small Indian mongoose (Herpestes auropunctatus) by Watari et al. (2011).

Meanwhile, the small Indian mongoose is considered as a valuable indicator for environmental monitoring because this species is an opportunistic predator that has been shown to have relatively high trace element levels in tissues. In animals at higher trophic levels, it is concerning that toxic effects by bio-accumulative contaminants of some

\footnotetext{
* Corresponding author at: Faculty of Agriculture, Tottori University, 4-101 Koyamacho-Minami, Tottori 680-8551, Japan.

E-mail address: horais@muses.tottori-u.ac.jp (S. Horai).
} 


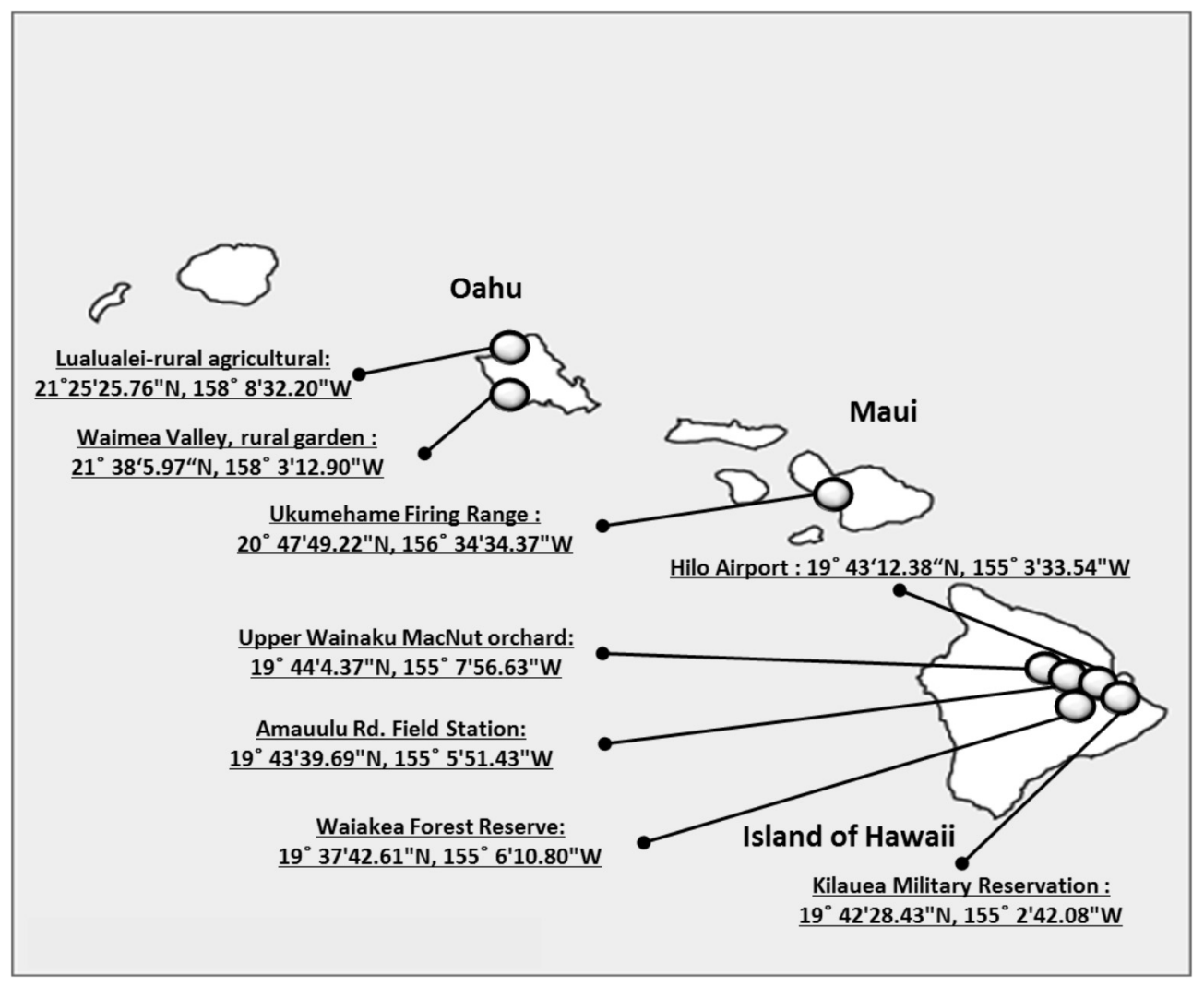

Fig. 1. Sampling locations of the small Indian mongooses in the Hawaiian islands, USA.

heavy metals have become more evident (Burger et al., 2000). Our study group previously conducted biomonitoring survey on trace elemental pollution in Japan, and found relatively high some metal levels in the mongoose population from Amamioshima (Horai et al., 2006) and Okinawa (Watanabe et al., 2010) compared with other terrestrial wildlife.

In Hawaii, rapid urban and small industrial development during the second half of the twentieth century, especially in Honolulu, has led to a degradation of the aquatic environment (De Carlo and Anthony, 2002). Metal contamination in the marine environment is a profound and biologically relevant problem in the main Hawaiian islands, where elevated concentrations of metals such as $\mathrm{Cr}, \mathrm{Cu}, \mathrm{Zn}$ and $\mathrm{Pb}$ in streambed sediments have been reported (McMurtry et al., 1995; De Carlo et al., 2005; Hédouin et al., 2009). The elevated metal levels are caused by an increase in human populations with high traffic densities, as well as by volcanic activity (McMurtry et al., 1995; Andrews and Sutherland, 2004). Furthermore, De Carlo et al. (2005) reported in National Water Quality Assessment (NAWQA) study that V, Cr, Cu and $\mathrm{Ni}$ in Oahu have been derived primarily from anthropogenic activity such as automotive traffic, population density and agricultural land use. Lead concentrations in selected fish species, Cuban limia (Limina vittata) and Mozambique tilapia (Oreochromis mossambicus), collected from the Manoa Stream in Oahu were the highest among data of 109 station recorded by the National Contaminant Biomonitoring Program (NCBP) station of the US Fish and Wildlife Service (Schmitt and Brumbaugh, 1990). There are some assessment studies of metal contamination in aquatic regions of Hawaii using sediments (De Carlo and Anthony, 2002; De Carlo et al., 2005; Hédouin et al., 2009; Hédouin et al. (2011)) and fishes (Schmitt and Brumbaugh, 1990). Although a few studies on contaminants have been conducted using roadside and road-deposited dust and soils also in the terrestrial regions of Hawaii (Sutherland et al., 2000; Sutherland et al. (2001)), the impact of metal contamination of terrestrial animals, especially higher trophic species, remains unexplored. Heavy metals enter aquatic ecosystems from urban, industrial, and agricultural runoff, and are augmented by natural geological processes (Mailman, 1980). Thus, characterizing the degree of trace element contamination on the Hawaiian terrestrial environment is important to manage and conserve both terrestrial and aquatic ecosystems. The objective of this study was to compare the trace element concentrations in the liver, kidney, muscle, brain, and hair of the small Indian mongoose collected from the Hawaiian Islands and to evaluate the contamination status of trace elements in the Hawaiian terrestrial environment.

\section{Materials and methods}

\subsection{Sample collection}

Liver, kidney, brain, and thigh muscle tissues, and hair of the small Indian mongoose were collected from 6 subadults and 38 adults inhabiting eight different areas (Lualualei-rural agricultural area, Waimea Valley-rural garden, Ukumehame firing range, Upper Wainaku macadamia nut orchard, Amauulu Road, Waiakea forest reserve, Hilo Airport, and Kilauea military reservation) in the three islands, Oahu, Maui, and Hawaii, during 2010-2013 (Fig. 1). Growth stage was determined by tooth-wear criteria (Woods and Sergile, 2001). In brief, all teeth of juveniles are sharp, whereas adult teeth are worn, broken and/ or rounded. Stomach content was collected from 23 adult individuals. Two females from the Upper Wainaku macadamia nut orchard samples of 38 adults had fetuses, and the liver, kidney, and brain were collected from each fetus. Sample data is shown in Table 1. All the tissue and stomach content samples were kept at $-25^{\circ} \mathrm{C}$ until chemical analysis.

All applicable international, national and/or institutional guidelines for the use of animals were followed. All procedures performed in studies involving animals were in accordance with the ethical standards of the institution at which the studies were conducted. 


\subsection{Chemical analysis}

All excised mongoose tissue samples were dried on petri dishes covered with Teflon sheets at $80^{\circ} \mathrm{C}$ for $16 \mathrm{~h}$, and then uniformly homogenized to a fine powder using a porcelain mortar. Approximately $0.1 \mathrm{~g}$ of the dried powder sample was digested in a microwave system with nitric acid. Concentrations of 26 elements ( $\mathrm{Li}, \mathrm{Mg}, \mathrm{Al}, \mathrm{Ca}, \mathrm{V}, \mathrm{Cr}$, $\mathrm{Mn}, \mathrm{Fe}, \mathrm{Co}, \mathrm{Ni}, \mathrm{Cu}, \mathrm{Zn}, \mathrm{Ga}$, As, Se, Rb, Sr, Mo, Ag, Cd, In, Sn, Sb, Ba, Pb and $\mathrm{Bi}$ ) were determined with an inductively coupled plasma-mass spectrometer (ICP-MS; HP4500, Hewlett-Packard, Avondale, PA, USA). Yttrium was used as an internal standard for ICP-MS measurements.

Accuracy of the analysis was verified using two standard reference materials, bovine liver (1577b) and DOLT (Dogfish liver tissue) -4 provided by the National Institute of Standards and Technology (NIST) and the National Research Council of Canada (NRC), respectively. The ranges of recovery rates of the elements in $1577 \mathrm{~b}$ and DOLT-4 samples by this procedure were from $90.2 \%(\mathrm{Ag})$ to $105 \%(\mathrm{Sr})$, and $86.4 \%(\mathrm{~V})$ to $106 \%$ (Mo), respectively. To compare with trace element levels from previous studies, dry weight concentrations obtained in this study were converted to a wet weight basis using water content values measured in this study; dry weight element concentration $\times(100$-water content in each sample (\%))/100 = wet weight element concentration.

\subsection{Statistical analysis}

Significant differences in concentrations among the sampling areas, and tissues were analyzed using the Steel-Dwass test. Differences of trace element concentrations between males and females were determined using Mann-Whitney's $U$ tests. Correlation between the metal concentrations in tissues was examined using the Spearman's rank test. A $p$ value less than 0.05 was considered to be statistically significant. All the statistical analyses were executed using the Statcel 3 program (Yanai, 2011).

\section{Results}

\subsection{Comparison of trace element concentrations among tissues}

Trace element concentrations in the liver, kidney, brain, muscle, hair, and stomach content samples of the small Indian mongooses collected from Hawaiian islands are shown in Table 2. In comparison to the levels among the four soft tissues, liver, kidney, brain, and muscle, significantly higher concentrations of $\mathrm{Al}, \mathrm{V}, \mathrm{Mn}, \mathrm{Fe}, \mathrm{Co}, \mathrm{Cu}, \mathrm{Zn}, \mathrm{Ga}$, and Mo were observed in the liver. In the kidney, $\mathrm{Ni}$, Se, and $\mathrm{Cd}$ concentrations were significantly higher than those in the other three tissues. Calcium and $\mathrm{Mg}$ concentrations were significantly higher in the brain and muscle when compared to the other tissues examined.

The metals and metalloids in the hair and stomach contents with significantly higher concentrations than in the four soft tissues were $\mathrm{Li}$, $\mathrm{Mg}, \mathrm{Al}, \mathrm{Ca}, \mathrm{V}, \mathrm{Cr}, \mathrm{Mn}, \mathrm{Fe}, \mathrm{Co}, \mathrm{Ni}, \mathrm{Zn}, \mathrm{Ga}, \mathrm{As}, \mathrm{Sr}, \mathrm{Ag}, \mathrm{Ba}$, and $\mathrm{Pb}$. Furthermore, $\mathrm{Al}, \mathrm{Ca}, \mathrm{Cr}, \mathrm{Zn}, \mathrm{Ga}, \mathrm{Sr}, \mathrm{Sn}, \mathrm{Ba}$ and $\mathrm{Pb}$ concentrations were significantly higher in the hair than in the stomach contents, while, $\mathrm{Li}$, $\mathrm{Mg}, \mathrm{V}, \mathrm{Mn}, \mathrm{Fe}, \mathrm{Co}, \mathrm{Ni}, \mathrm{As}$, and Ag concentrations in the stomach contents were significantly higher contents than those in the hair.

\subsection{Comparisons of trace element concentrations between dams and fetuses}

To understand the transference of trace elements from dam to fetus, we compared the trace element concentrations in liver, kidney, and brain tissues of the two pairs of dams and fetuses (Table 3). The fetus/ dam ratios of the trace element concentrations in each tissue are shown in Fig. 2. In the liver, fetus/dam ratios of $\mathrm{Ca}, \mathrm{Cu}, \mathrm{Sr}$, and $\mathrm{Ba}$ concentrations were more than 2.0, and in the kidney, the ratios of $\mathrm{Li}, \mathrm{Ca}$, $\mathrm{Cr}, \mathrm{Fe}, \mathrm{Ni}$, and $\mathrm{Ba}$ concentrations exceeded 2.0 in both pairs. As for the brain, the trace elements that showed the ratios more than 2.0 were $\mathrm{Li}$, $\mathrm{Al}, \mathrm{Ca}, \mathrm{Ni}, \mathrm{Ga}, \mathrm{Ba}$, and $\mathrm{Pb}$. Especially, concentrations of alkali-earth 


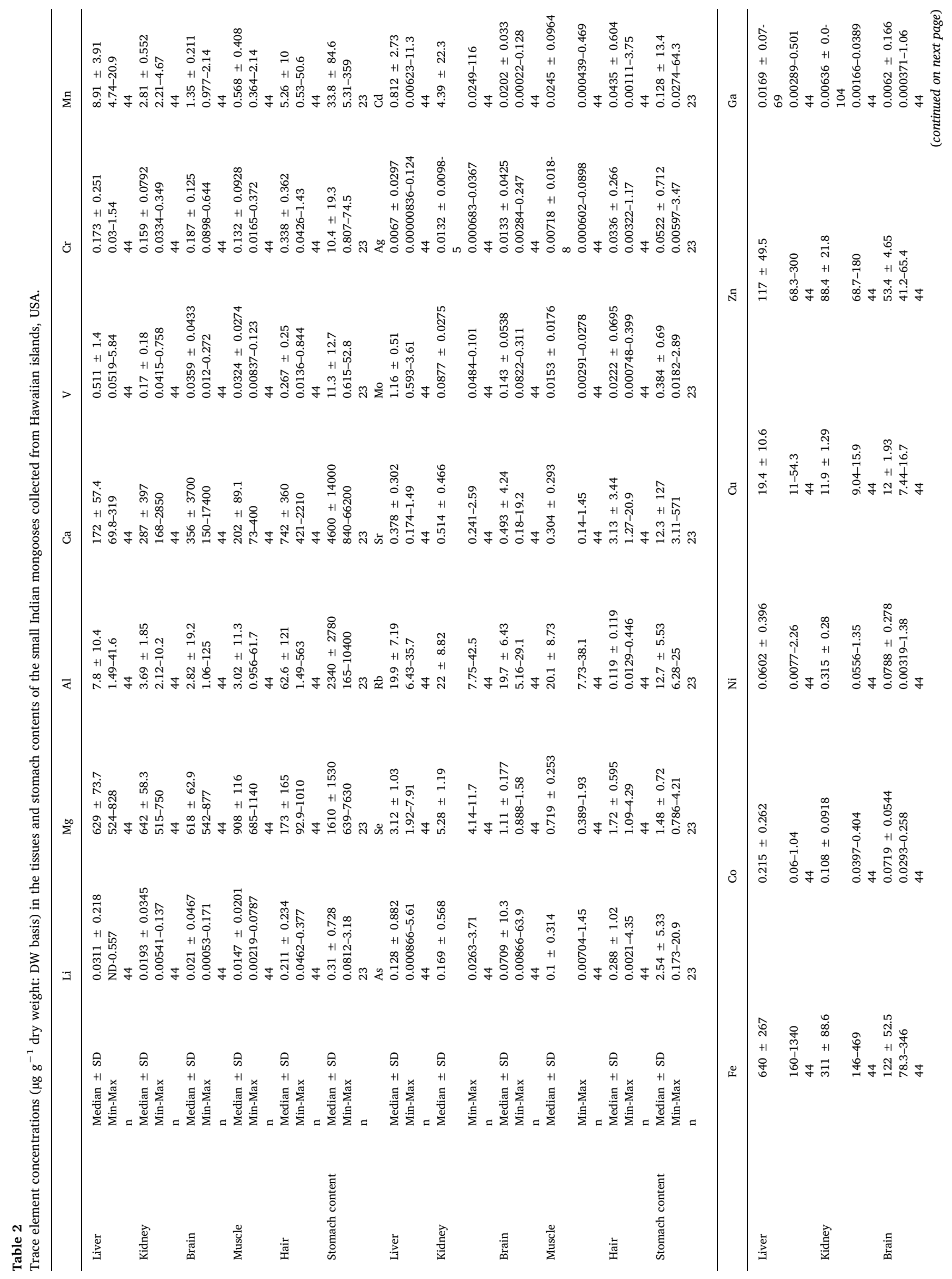




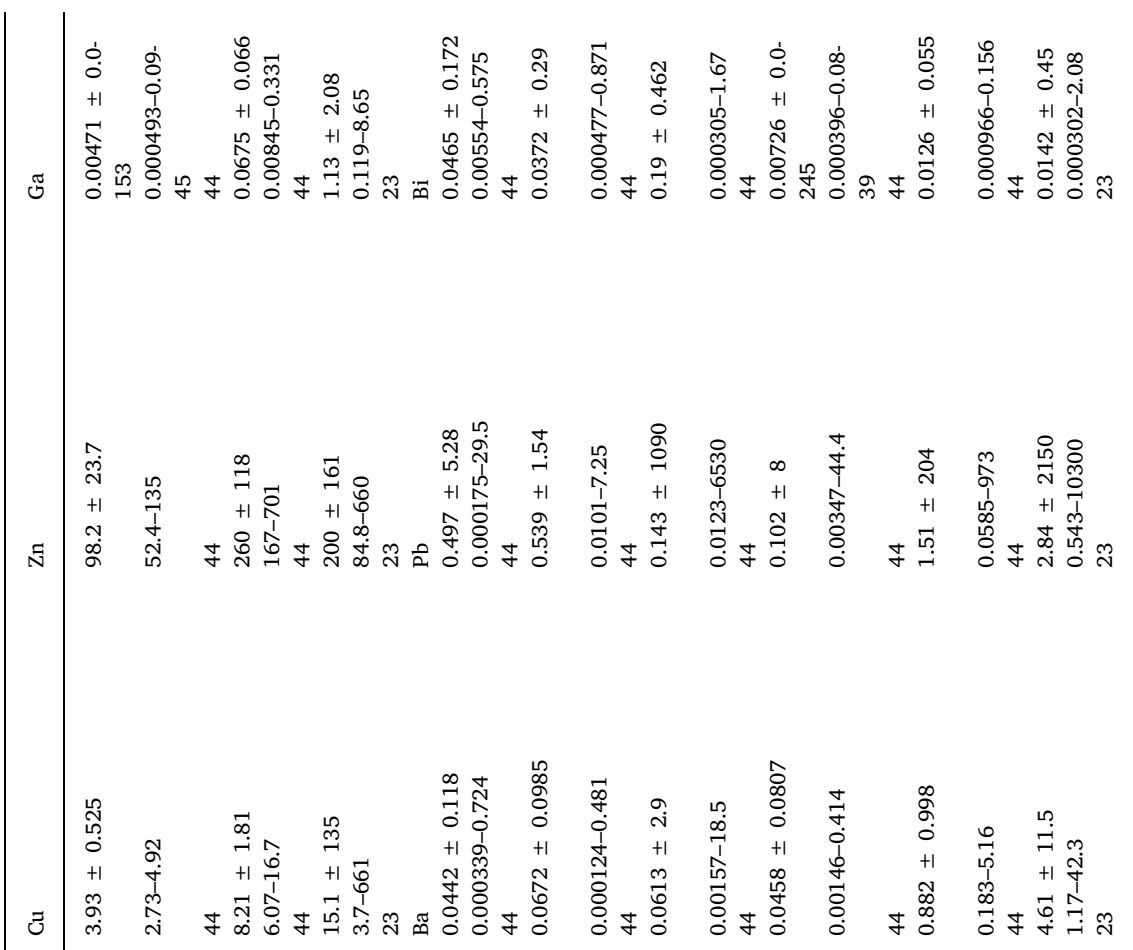

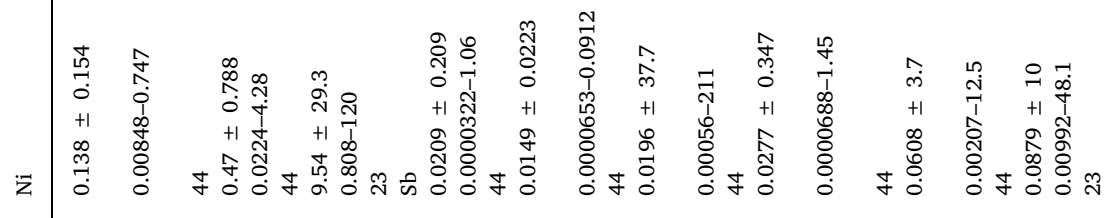

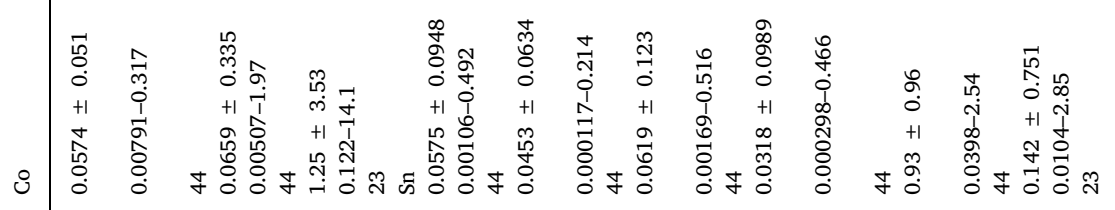

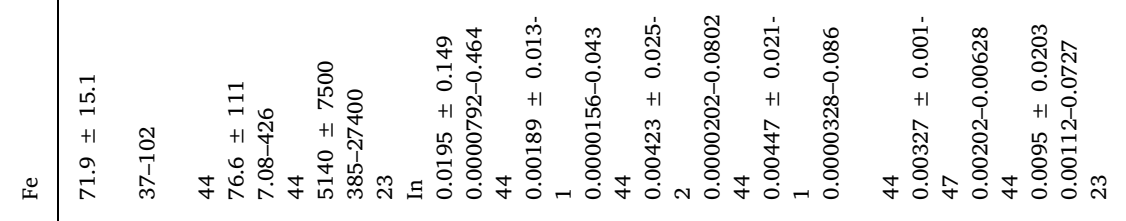

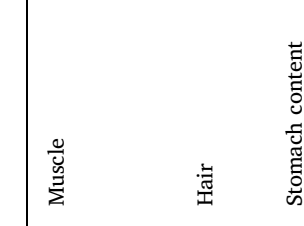

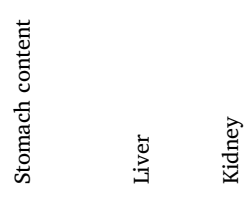

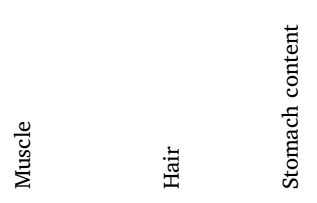




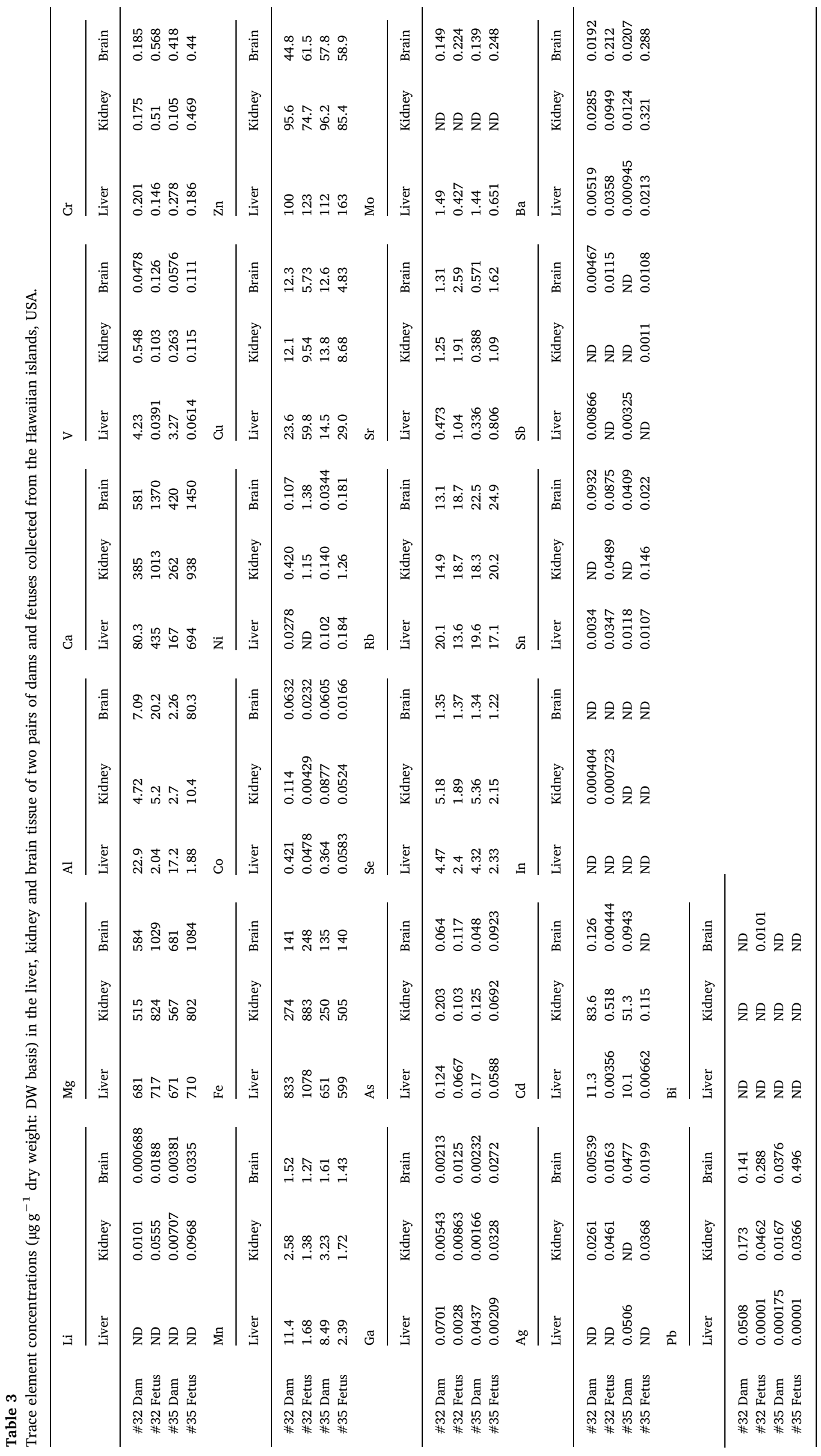




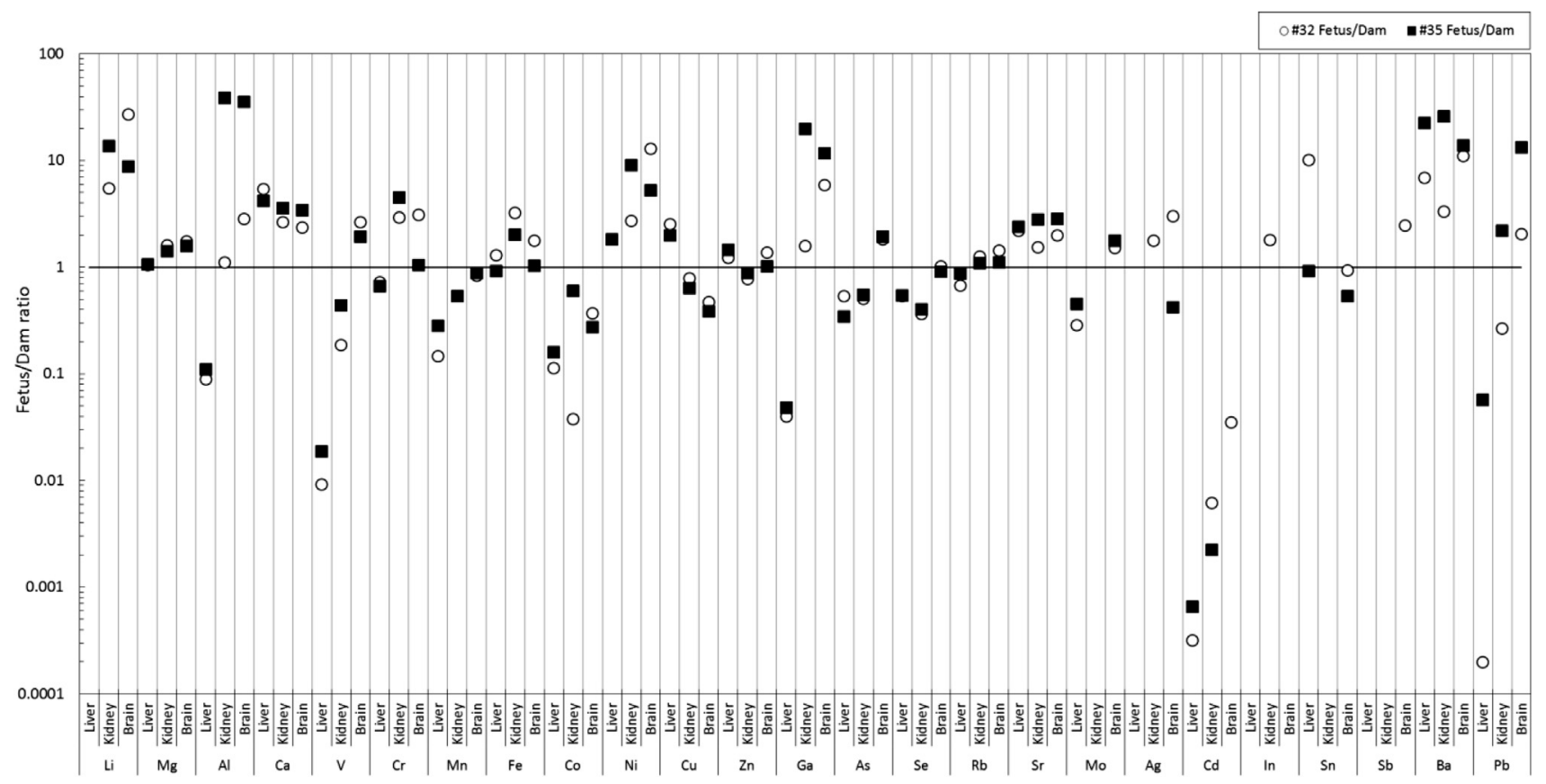

Fig. 2. Fetus/dam ratios of trace element concentrations in liver, kidney and brain tissues of the two pairs (\#32 ( $O$ ) and \#35 ( $\square$ )) of fetuses and dams.

metals, such as $\mathrm{Ca}$ and $\mathrm{Ba}$, were higher in all tissues of the fetuses than in the dams. Thus, larger numbers of trace elements that showed the fetus/dam ratios more than 2.0 were found in the brain. For instance, $\mathrm{Pb}$ concentrations in the brain of the fetuses were higher than those of the dams, but the $\mathrm{Pb}$ levels in the fetus livers were lower compared to their dams. Similar trends were also observed also for V and As.

\subsection{Comparisons of $\mathrm{Ni}, \mathrm{Cd}, \mathrm{Pb}$ concentrations in tissues from Hawaiian islands to other regions}

We compared the tissue levels of trace elements in the small Indian mongooses analyzed in this study with tissue data reported in the same species from mainland Kyusyu (Kagoshima), Amamioshima island and Okinawa island (Ryukyu Archipelago) (Watanabe et al., 2010; Horai et al., 2006; Unpublished data).

Of the four soft tissues from the Hawaiian mongooses, Ni and Cd concentrations were highest in the kidney, and the renal $\mathrm{Ni}$ concentrations were significantly higher in Hawaii mongooses than those from Kagoshima and Amamioshima (Fig. 3a). Also in the brain, significantly higher Ni levels were observed in the specimens from Hawaii than Kagoshima, but there was no significant difference between Hawaii and Amamioshima (Fig. 3b). Similarly, liver Ni residues in mongooses were higher in Hawaii than in Kagoshima but comparable to those in Amamioshima. In contrast, there was no significant difference of Cd levels in the kidney from Hawaii and the other Japanese locations, however, a wider range of Cd concentrations was observed among Hawaiian mongoose samples (Fig. 3c).

Comparisons of $\mathrm{Pb}$ concentrations in the liver, kidney, and brain among the four areas are shown in Fig. 4. In the liver, the $\mathrm{Pb}$ levels in mongooses from Hawaii were significantly lower than those from Amamioshima (Fig. 4a), and there were no significant differences in the renal $\mathrm{Pb}$ levels between Hawaii and each Japanese habitat (Fig. 4b). However, the $\mathrm{Pb}$ concentrations in the brain from Hawaii were significantly higher than those from Kagoshima and Amamioshima (Fig. 4c).

\subsection{Spatial differences in $\mathrm{Ni}, \mathrm{Cd}$, and $\mathrm{Pb}$ concentrations in tissues from Hawaiian islands}

As shown in Figs. 3 and 4, a wide range of $\mathrm{Ni}, \mathrm{Cd}$, and $\mathrm{Pb}$ concentrations was observed in the small Indian mongooses from Hawaii. Therefore, we examined spatial differences in concentrations of these metals in tissues.

There were no significant differences in Ni concentrations in the kidneys of mongooses among the eight locations of Hawaiian islands (Fig. 5a). However, significant differences in Cd concentrations in the kidneys were found; the specimens from the Ukumehame military firing range showed lower levels than those from the macadamia nut orchard, Amauulu, Hilo Airport and Kilauea military reservation in Hawaii island (Fig. 5b). When classifying the eight locations into three island groups, Oahu, Maui, and Island of Hawaii, Cd concentrations in the Island of Hawaii were significantly higher than those in Oahu $(p<0.05)$ and Maui $(p<0.01)$.

There were no significant differences of $\mathrm{Pb}$ concentrations in the liver and kidney of the small Indian mongooses collected from the eight areas in Hawaii, although the median $\mathrm{Pb}$ concentrations in each organ from the Ukumehame military firing range were the highest among all the locations (Fig. $6 \mathrm{a}$ and $\mathrm{b}$ ). The median $\mathrm{Pb}$ concentration in the brain from the firing range was $12.1 \mu \mathrm{g} \mathrm{g}^{-1} \mathrm{DW}$, which was considerably higher than median values from the other locations, with the levels significantly higher than those from the Kilauea military reservation (Fig. 6c).

We examined the relationship of $\mathrm{Pb}$ with $\mathrm{As}$ or $\mathrm{Sb}$ concentrations at the Ukumehame firing range (Fig. 7a) and at seven other locations (Fig. 7b). Significant correlations between $\mathrm{Pb}$ and As or Sb concentrations were observed in the brain, and hair from the firing range, while there were significant correlations for hair from the other seven zones (Fig. 7a and b). The slopes between As and $\mathrm{Pb}$ concentrations in the hair $(\mathrm{y}=0.0085 \mathrm{x}+0.183 ; r=1.00)$ and the brain $(\mathrm{y}=0.0097 \mathrm{x}-0.0431$; $r=1.00)$ and between $\mathrm{Sb}$ and $\mathrm{Pb}$ concentrations in the hair $(\mathrm{y}=0.0249 \mathrm{x}+0.408 ; r=0.979)$ and the brain $(\mathrm{y}=0.0325 \mathrm{x}-0.706$; $r=1.00$ ) from the firing range were approximate each other (Fig. 7). 


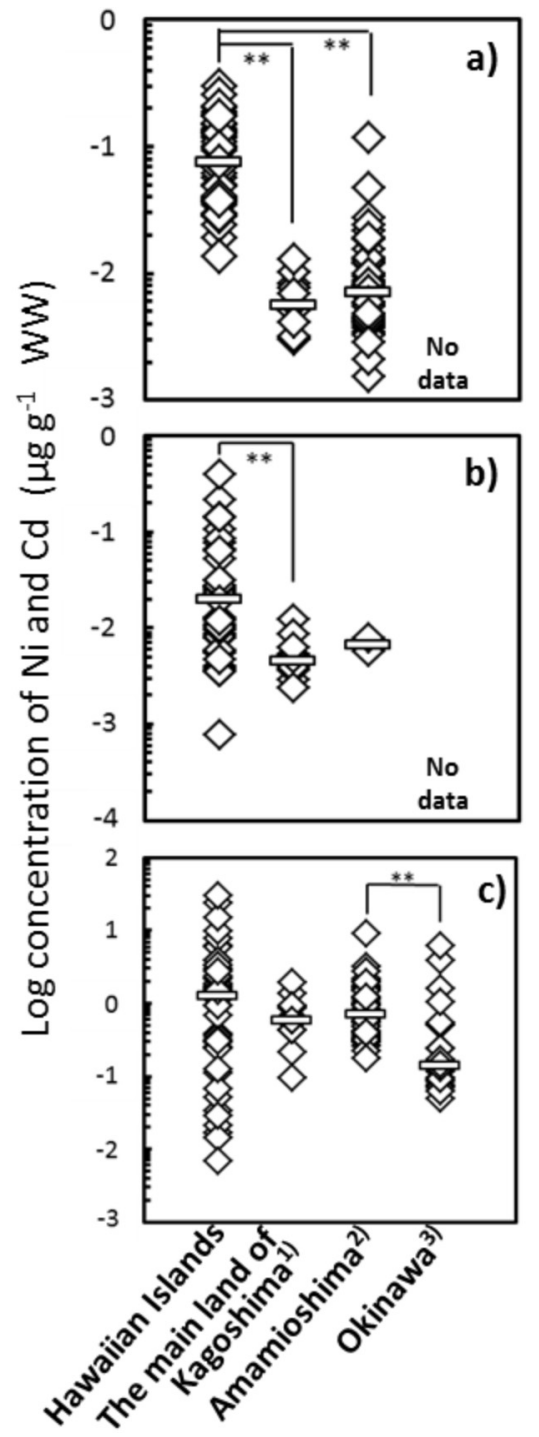

Fig. 3. Comparisons of Ni concentrations in the a) kidney and b) brain, and c) Cd concentrations in the kidney of the small Indian mongooses from Hawaii with data of specimens from the three habitats in Japan. 1,3) Watanabe et al., 2010, 2) Horai et al., 2006.

\section{Discussion}

Anthropogenic activities can cause widespread accumulation of heavy metals, which when not submitted to natural biodegradation can accumulate in living organisms and circulate in trophic chains (DamekPoprawa and Sawicka-Kapusta, 2003). The use of a bioindicator species can provide valuable data in monitoring the quality of the environment through exposure and accumulation of contaminants in the animal habitat (Adham et al., 2011). In the present study, concentrations of 26 trace elements including essential and toxic elements were determined in the liver, kidney, muscle, hair, and stomach content of 44 small Indian mongooses collected from eight locations in the three Hawaiian islands; Oahu, Maui, and the Island of Hawaii.

Essential metal concentrations of $\mathrm{Mn}, \mathrm{Fe}$ and $\mathrm{Cu}$ were higher in the liver than in the kidney, muscle and brain. This pattern was consistent with previous studies observed in mongooses collected from Okinawa (Watanabe et al., 2010), Amamioshima (Horai et al., 2006), and Kagoshima (Watanabe et al., 2010). Iron is distributed mainly in the liver as stored Fe in some terrestrial mammalian species such as rat, rabbit, brown bear (Ursus arctos), gray wolf (Canis lupus), Eurasian lynx (Lynx lynx), golden jackal (Canis aureus) (Lazarus et al., 2017) and humans

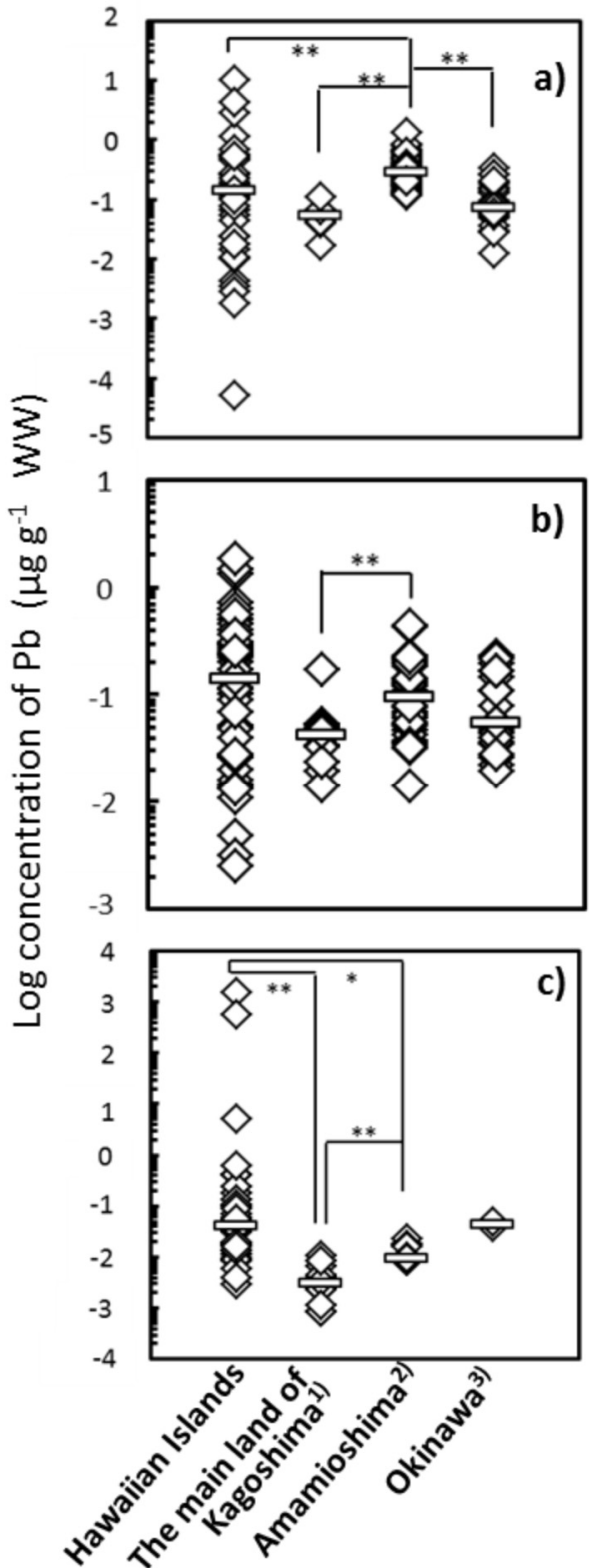

Fig. 4. Comparisons of $\mathrm{Pb}$ concentrations in the a) liver, b) kidney and c) brain of the small Indian mongooses from Hawaii with data in specimens from the three habitats in Japan. 1,3) Watanabe et al., 2010, 2) Horai et al., 2006.

(Underwood, 1977). Among the body organs, the liver and spleen usually show the highest Fe concentrations, followed by the kidney, heart, skeletal muscle, and brain, which contain only half to one-tenth of the levels in the liver and spleen (Underwood, 1977). In some marine mammals, such as fin whale (Balaenoptera physalus), Risso's dolphin (Grampus. griseus), striped dolphin (Stenella. coeruleoalba) and common bottle-nose dolphin (Tursiops. Truncatus) (Capelli et al., 2008), it has been shown that Fe concentrations in the livers were higher than those in the muscle and kidney.

It is known that liver is the organ with the highest $\mathrm{Cu}$ content in some mammalian species (Underwood, 1977). Higher levels of $\mathrm{Cu}$ in the liver than in other organs have been also found in humans (Wada, 1985) and some wild mammals such as small rodents (Fritsch et al., 2010), brown bear, gray wolf, Eurasian lynx, golden jackal (Lazarus et al., 2017), harbor seal (Phoca vitulina) (Agusa et al., 2011), Caspian seal (Phoca caspica) (Watanabe et al., 2002), Baikal seal (Phoca sibirica) (Watanabe et al., 1996), S. coeruleoalba, T. truncates, and Ziphius. 


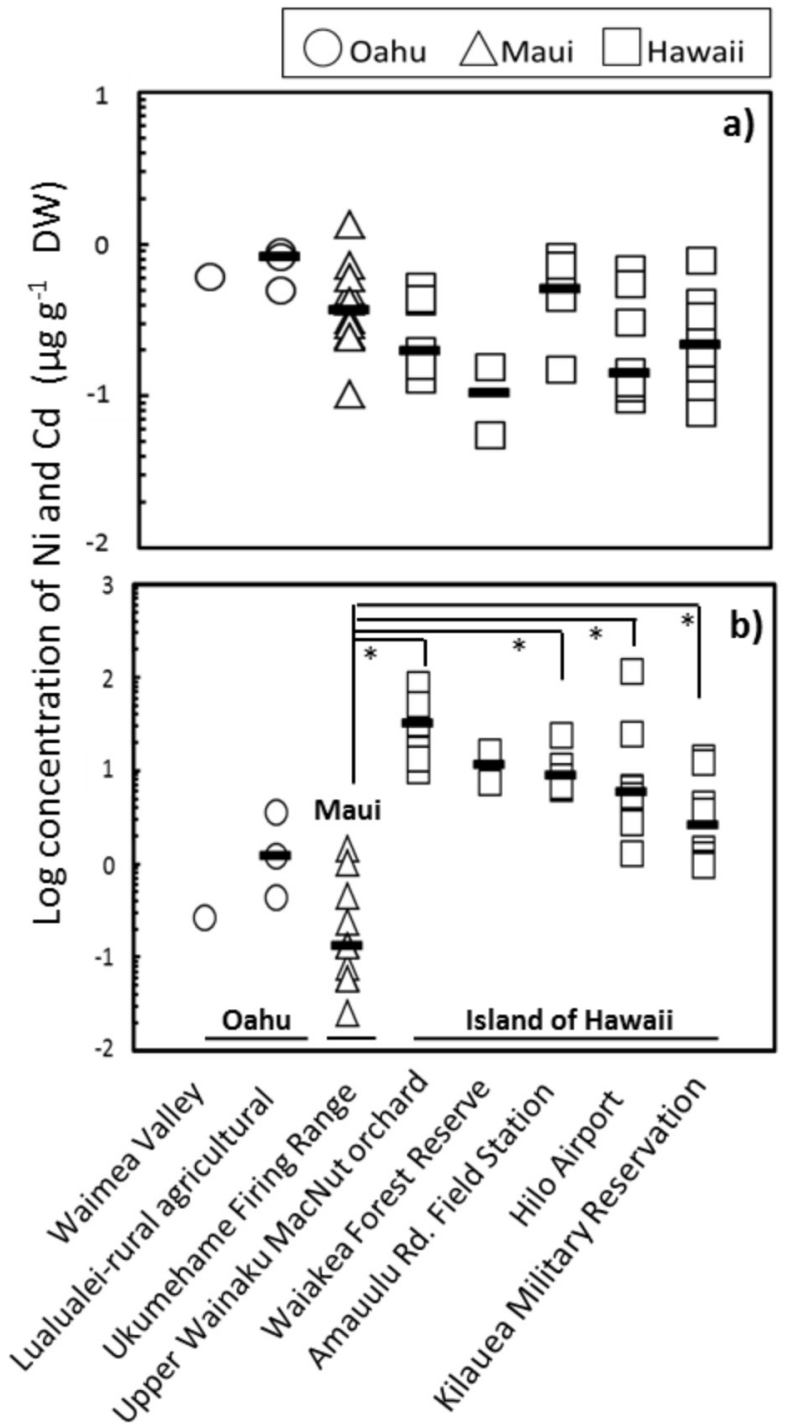

Fig. 5. Comparisons of a) $\mathrm{Ni}$ and b) Cd concentrations in the kidney of the small Indian mongooses from eight different habitats of the Hawaiian islands.

cavirostris (Capelli et al., 2008). Moreover, an avian species, the great cormorant (Phalacrocorax carboalso) had higher $\mathrm{Cu}$ levels in the liver compared with other organs (Nam et al., 2005). Similarly, relatively higher concentrations of $\mathrm{Mn}$ in the liver have been shown in humans (Underwood, 1975; Wada, 1985), some wild terrestrial mammals (Lazarus et al., 2017), and marine mammals (Watanabe et al., 1996, 2002, Capelli et al., 2008, Agusa et al., 2011), and avian species (Nam et al., 2005, Horai et al., 2007).

In mongooses from the Hawaiian Islands, Cd concentrations were the highest in the kidney of the four soft tissues analyzed. This result was consistent with data reported in the mongoose populations from four habitats in Japan (Horai et al. 2006; Watanabe et al., 2010) In the case of humans, it is known that Cd exists mainly in the kidney (Underwood, 1975). In some terrestrial mammals (Fritsch et al., 2010; Lazarus et al., 2017), marine mammal (Watanabe et al., 1996, 2002, Capelli et al., 2008, Agusa et al., 2011; Reed et al. 2015, Mahfouz et al., 2014), and avian species (Nam et al., 2005; Horai et al., 2007; Zaccaroni et al., 2011; Cui et al., 2013), the Cd accumulation was more abundant in the kidney than in the other organs and tissues. Together, distribution patterns of $\mathrm{Mn}, \mathrm{Fe}, \mathrm{Cu}$ and $\mathrm{Cd}$ in the liver and kidney of small Indian mongoose population from Hawaii were similar to mongooses from Japan as well as other terrestrial and marine mammals. Cadmium concentration in the brain of small Indian mongoose and other terrestrial mammals were similar to European otter (Lutra lutra), mustelids (Martes martes, M. foina, Mustela putorius) and raccoon (Nyctereutes procynoides) (Kalisinska et al., 2016).

Understanding the transference of trace elements between dam and fetus in wild mammals may provide useful information on future generation effects of metal exposure in humans, but there are limited studies in this regard. In the present study, we showed the distribution pattern of trace elements by analyzing liver, kidney, and brain samples from two pairs of fetus and dam. The fetus/dam concentration ratios of $\mathrm{Ca}$ and Ba exceeded 2.0 in the liver, kidney, and brain (Fig. 2). Rossipal et al. (2000) reported in humans that Ca concentrations in umbilical cord sera (UCS) were significantly higher $(p<0.005)$ than those in maternal serum; the median level in UCS amounted to $120 \%$ of the maternal value. Thus, it is likely that the physiological requirement of $\mathrm{Ca}$ in the fetus is relatively high.

However, Se and Cd concentrations in the liver and kidney tissues of fetuses were lower than those in the two respective organs of their dams (Fig. 2). Similar phenomena were previously reported in fetus-dam pairs of common dolphins (Delphinus delphis) (Lahaye et al., 2007). In the present study, higher concentrations of 11 elements $(\mathrm{Mg}, \mathrm{Al}, \mathrm{Ca}, \mathrm{V}$, $\mathrm{Cr}, \mathrm{Ga}, \mathrm{As}, \mathrm{Rb}, \mathrm{Sr}, \mathrm{Ba}$, and $\mathrm{Pb}$ ) in the brain, 3 elements ( $\mathrm{Ni}, \mathrm{Cd}$, and $\mathrm{Sn}$ ) in the kidney, and 7 elements ( $\mathrm{Mn}, \mathrm{Fe}, \mathrm{Co}, \mathrm{Cu}, \mathrm{Zn}, \mathrm{Se}$, and $\mathrm{Mo}$ ) in the liver were found in the fetuses than in the dams. Thus, more elements with higher levels than in dams accumulated in the brain of the fetuses (Fig. 2). It has been reported in experimental animals that parental exposure to some hazardous chemicals induces developmental dysfunction in the central nervous system of offspring (Kuwagata et al., 2009). In particular, fetuses and young children are at the greatest risk on neurotoxic effects by Pb exposure (ATSDR, 2007). Lead can cross the placenta and reach the developing brain of the fetus, whose incomplete blood barrier makes it more vulnerable to toxicant exposure than that in adults (Grandjean and Lanrigan, 2007).

Nickel, $\mathrm{Cd}$ and $\mathrm{Pb}$ concentrations were relatively higher in the organs of small Indian mongooses from the Hawaiian islands as compared to mongooses from Japan, suggesting the considerable pollution by the three metals in Hawaii. Records show environmental bioaccumulation/ pollution of these three metals potentially from sustained natural (vocanic), agricultural (sugarcane) or small industrial sources. Nickel and $\mathrm{Pb}$ residues in Hawaii has been reported by De Carlo et al. (2005) and Schmitt and Brumbaugh (1990) from chemical analysis of sediment and fish samples. The results of the present study are consistent with their findings although sample species were different. Cadmium levels in Island of Hawaii were found to be significantly higher than those in Oahu and Maui, suggesting the regional difference in Cd pollution (Fig. 5). According to the Hawai'i Department of Health Hazard Evaluation and Emergency Response (DOH HEER, 2012), Cd concentrations in soils in Hawaii island (median; $0.840 \mathrm{mg} / \mathrm{kg}$ ) were significantly higher than those in Maui (median; $0.395 \mathrm{mg} / \mathrm{kg}, p<0.05$ ), and relatively higher than those in Oahu (median; $0.775 \mathrm{mg} / \mathrm{kg}$ ). None of the soil samples from 32 locations in Hawaii Island were below the detection limit (LOD), whereas 15 of 41 samples from Oahu and 5 of 23 samples from Maui were below the LOD (DOH HEER, 2012). This higher Cd background levels on Hawaii island as compared to Maui and Oahu coincides our data of $\mathrm{Cd}$ bioaccumulation mongooses between the three Hawaii islands.

Higher Cd environmental background levels in Hawaii island may be an artifact of island geographic differences. Cd concentrations in soils tend to increase with higher clay content, and Cd shows stronger correlations with levels of $\mathrm{Fe}, \mathrm{Mn}$, and organic matter (DOH HEER, 2012). In examining soil order classifications, it was found that the proportions of basaltic soils (lava flows) and histosols which are organic soils containing over $50 \%$ organic matter, on Hawaii Island were markedly higher than those on Maui and Oahu islands (DOH HEER, 2012). Anthropogenic Cd tends to accumulate in surface soils due to atmospheric deposition (from fossil fuel combustion and certain industrial activities) and the application of fertilizers to agricultural land 


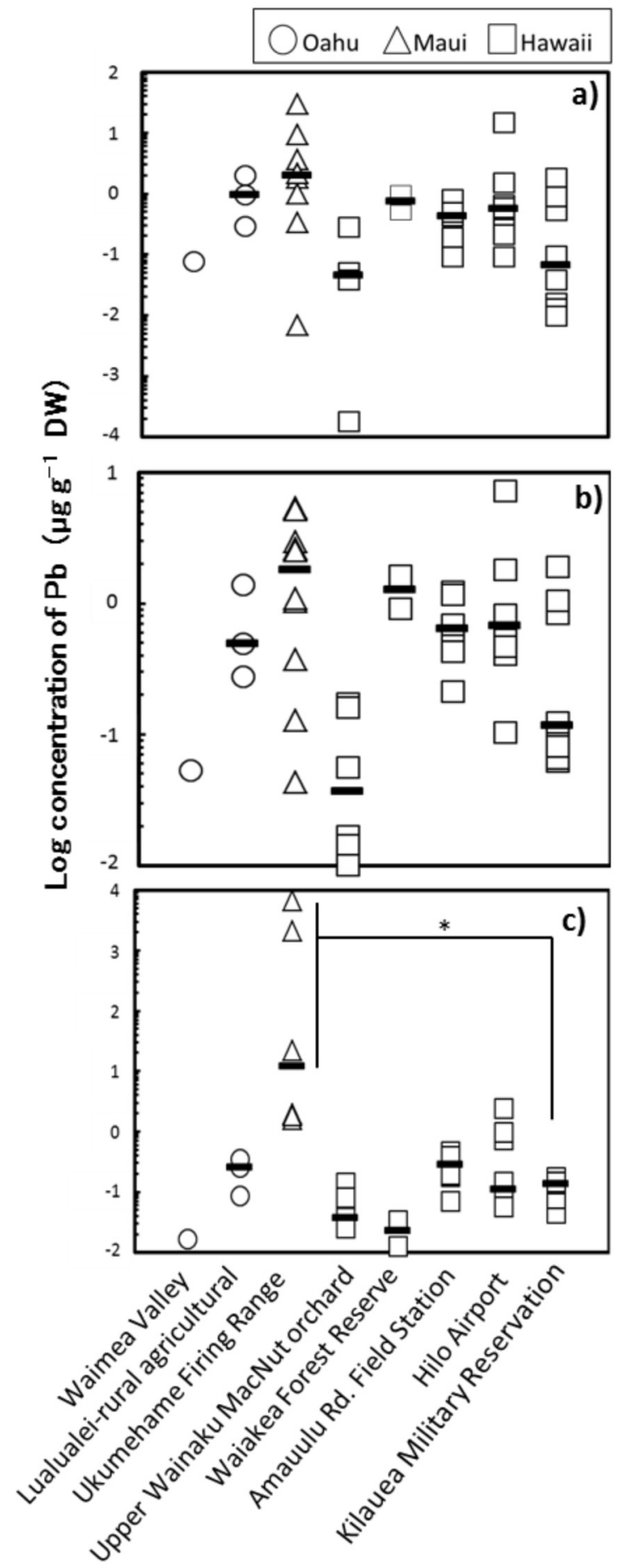

Fig. 6. Comparisons of $\mathrm{Pb}$ concentrations in the a) liver, b) kidney and c) brain of the small Indian mongooses from eight different habitats in Hawaiian islands.

\section{(DOH HEER, 2012).}

Comparisons of $\mathrm{Pb}$ concentrations in the liver, kidney, and brain among the four areas have been shown in Fig. 4. Lead concentration in brain tissues from Hawaii was especially noteworthy. In Hawaii, $\mathrm{Pb}$ levels in the brain of small Indian mongooses from the Ukumehame military firing range were relatively higher than those in other seven locations; the median (min-max) values $\left(\mu \mathrm{g} \mathrm{g}^{-1} \mathrm{WW}\right.$ ) were 0.004 $(\mathrm{n}=1), \quad 0.0688 \quad(0.0136-0.0887), \quad 2.68 \quad(0.395-1510), \quad 0.0088$ (0.00597-0.0354), $\quad 0.00607 \quad(0.00288-0.00925), \quad 0.0715$ (0.0156-0.129), $0.0268(0.0134-0.614), 0.037(0.0111-0.0598)$ for Waimea Valley, Lualualei-rural agricultural, Ukumehame military firing range, Upper Wainaku macadamia nut orchard, Waiakea forest reserve, Amauulu Rd., Hilo Airport, Kilauea military reservation, respectively (Fig. $6 \mathrm{c}$ ). The median $\mathrm{Pb}$ values from the firing range was highest compared to some wild terrestrial (Kalisinska et al., 2016) and marine (Cardellicchio et al., 2002; Romero et al., 2017) mammals. Lead concentrations in all the brain samples from the Ukumehame firing range and two of the eight from Hilo Airport exceeded the mean $\mathrm{Pb}$ level observed in the brain of male rats $\left(0.239 \mu \mathrm{g} \mathrm{g}^{-1} \mathrm{WW}\right)$, which were exposed to $50 \mathrm{mg} / \mathrm{L} \mathrm{Pb}$ and had increased ambulatory activity measured as lines crossed (Mansouri et al., 2012). Cao et al. (2013) reported that rats exposed to $\mathrm{PbS}$ nanoparticles showed an increased average number of errors and escape latency, and their hippocampi had pathologically changed. The average $\mathrm{Pb}$ levels in the hippocampus and cortex of rats were approximately 1.5 and $0.9 \mu \mathrm{g} \mathrm{g}^{-1} \mathrm{WW}$ in the low dose group, and approximately 2.1 and $1.4 \mu \mathrm{g} \mathrm{g}^{-1} \mathrm{WW}$ in the high dose group, respectively. In the present study, the median $\mathrm{Pb}$ level in the brain of the small Indian mongoose from the Ukumehame firing range exceeded $2.1 \mu^{-1} g^{-1}$ WW. Dewanjee et al. (2013) examined the toxic effects of $\mathrm{Pb}$ exposure in Wister rats, and reported the mean cerebral $\mathrm{Pb}$ level in the rats exposed to $\mathrm{Pb}$-acetate was $3.79 \mu \mathrm{g} \mathrm{g}^{-1} \mathrm{WW} \pm 0.25$, and showed significant decreases in the number of total erythrocytes, monocytes, and neutrophils. Moreover, cellular necrosis, diffused edema, and encephalomacia were observed in the rat brain. There were three individuals from the Ukumehame firing range which exceeded $3.79 \mu \mathrm{g} \mathrm{g}^{-1} \mathrm{WW}$ in brain tissue. Interestingly, $\mathrm{Pb}$ concentrations in the subadult brains were relatively higher than those in the adults from the Ukumehame firing range (Suppl. 1). As described earlier, Pb levels in the brain of two fetuses were also higher than those in their dams from the Wainaku macadamia nut orchard (Suppl. 2). Brain is thought to be a target organ on $\mathrm{Pb}$ toxicity, especially fetuses and subadults.

One of the signs of $\mathrm{Pb}$ intoxication in vertebrate animals consists of a reduction in body weight (Goyer et al., 1970; Ma, 1989). Ma (1989) reported body weight reduction in wood mice (Apodemus sylvaticus) from an area polluted with $\mathrm{Pb}$ pellets from shotgun ammunition. In the present study, the median body weight of adult females $(n=3)$ from the firing range was $400 \mathrm{~g}$, whereas that from all other areas $(n=12)$ was $450 \mathrm{~g}$. On the contrary, the median body length from the firing range specimens was similar to that from others $(29.5 \mathrm{~cm})$. The body weight of only one adult male individual from the firing range was $378 \mathrm{~g}$. The median body weight of adult males from other areas $(\mathrm{n}=22)$ was $697 \mathrm{~g}$. The difference in the median body weights between two groups correlates to their body lengths; one from the firing range was $27.0 \mathrm{~cm}$ and another from the other areas was $31.5 \mathrm{~cm}$. However, the body weight of an adult male from the other area which had similar body length $(27.5 \mathrm{~cm})$ to the one from the firing range $(27 \mathrm{~cm})$ was $421 \mathrm{~g}$. These observations suggest that body weight reduction in adult mongooses from Ukumehame firing range may be correlated to increased $\mathrm{Pb}$ bioaccumulation.

We compared $\mathrm{Pb}$ concentrations among the liver, kidney, muscle, brain, and hair by separating the sampling locations into two groups, the firing range and all other areas. For the both groups, the highest $\mathrm{Pb}$ concentrations were found in the hair; the tissue with the second highest levels were the brain for the Ukumehame firing range and kidney for other locations (Suppl. 3).

The distribution of $\mathrm{Pb}$ in mammalian tissues generally reflects the following order: bone $>$ kidney $>$ liver $>$ brain $>$ muscle (Ma, 1996). In previous studies, kidney was the main organ of $\mathrm{Pb}$ concentration in the soft tissues of small mammals such as wood mice (Apodemus sylvaticus), bank voles (Clethrionomys glareolus), shrews (Sorex araneus), white-footed mice (Peromyscus leucopus), and shorttail shrew (Blarina brevicauda) from a shooting range (Ma 1989; Stansley and Roscoe, 1996). In the present study, brain was the main organ of $\mathrm{Pb}$ accumulation in the soft tissues of mongoose from the firing range. No significant differences in $\mathrm{Pb}$ concentrations between liver and kidney were found. There were no specimens that exceeded $25 \mu \mathrm{g} / \mathrm{g}$ DW of renal $\mathrm{Pb}$ concentration which was considered diagnostic of $\mathrm{Pb}$ 


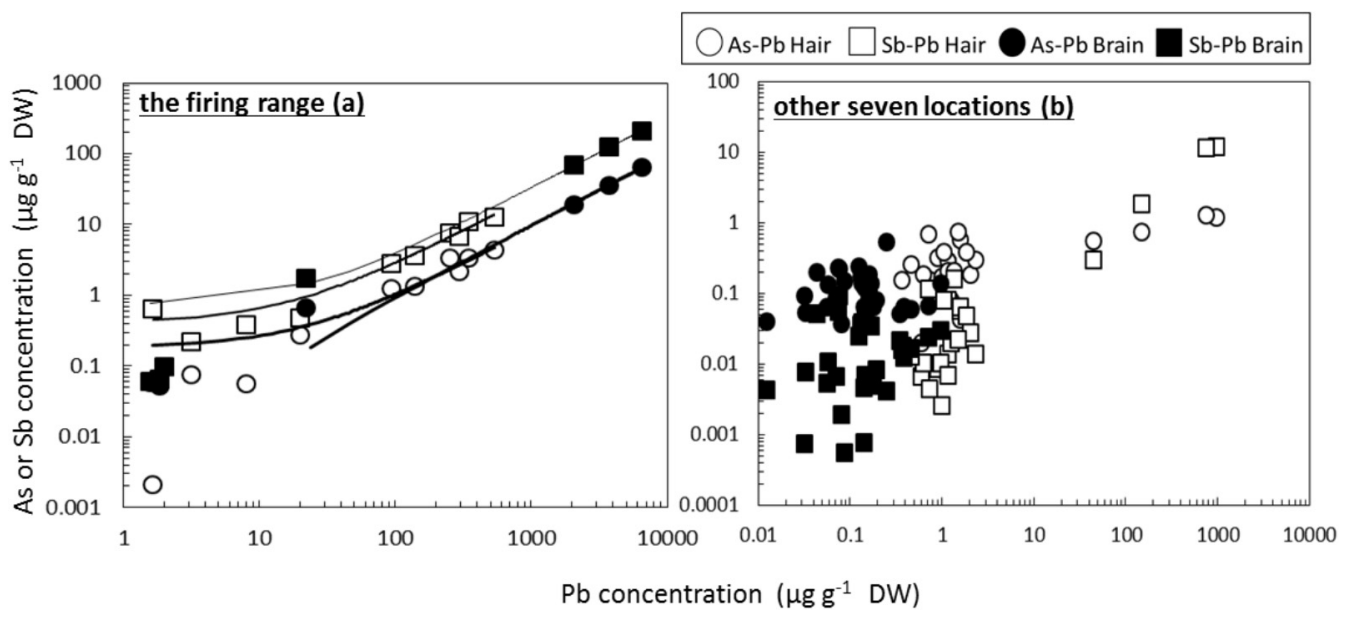

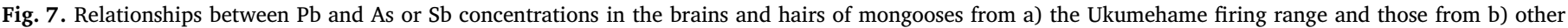
seven locations.

intoxication in mammals (Ma, 1989), whereas hepatic $\mathrm{Pb}$ concentration (29.5 (9.79) $\mu \mathrm{g} / \mathrm{g}$ DW (WW)) in one mongoose exceeded this value. Lewis et al. (2001) categorized hepatic and renal $\mathrm{Pb}$ levels in avian and mammalian species as background at $<1 \mu \mathrm{g} / \mathrm{g}$ WW, indication of subclinical exposure at $1-2 \mu \mathrm{g} / \mathrm{g} \mathrm{WW}$, and potential clinical $\mathrm{Pb}$ poisoning at $6 \mu \mathrm{g} / \mathrm{g}$ WW or more. In the present study, median $\mathrm{Pb}$ concentrations in the liver and kidney from the firing range were 1.97 (0.547) and $1.79(0.422) \mu \mathrm{g} / \mathrm{g}$ DW (WW), respectively. In contrast, the medians of $\mathrm{Pb}$ concentrations in the two soft tissues from other locations were $0.461(0.119) \mu \mathrm{g} / \mathrm{g} \mathrm{DW}(\mathrm{WW})$ in the liver and 0.679 (0.114) $\mu \mathrm{g} / \mathrm{g}$ DW (WW) in the kidney. Comparing to above Lewis' classification (2001), Pb levels in the liver and kidney in six of nine individuals (66.7\%) from the firing range exceeded $1 \mu \mathrm{g} / \mathrm{g} W W$, whereas the concentrations in three livers (8.57\%) and six kidneys (17.1\%) of 35 specimens from the other zones were more than the considered normal value. Namely, the proportion of mongooses from the firing range which exceeded the normal value of $\mathrm{Pb}$ concentration was higher than that from the other areas. Moreover, $\mathrm{Pb}$ levels in the two livers exceeded $2 \mu \mathrm{g} / \mathrm{g}$ WW. In the other locations, there was one specimen from Hilo airport that had hepatic and renal $\mathrm{Pb}$ concentrations exceeded $1 \mu \mathrm{g} / \mathrm{g}$ WW; the values were 4.32 and $1.84 \mu \mathrm{g} / \mathrm{g} \mathrm{WW}$, respectively.

There were significant positive correlations between $\mathrm{Pb}$ and $\mathrm{As}$ or $\mathrm{Sb}$ concentrations in the brain and hair from the firing range (Fig. 7a). Moreover, the slopes in the concentrations of $\mathrm{Pb}$ and $\mathrm{As}$ or $\mathrm{Sb}$ from the firing range were similar between the brain and hair (Fig. 7a). However, such correlations were not observed for the other seven locations (Fig. 7b). Lead shot pellets generally contain As and Sb, which are added to increase hardness (Krachler et al., 2001). Takamatsu et al. (2010) reported that proportional ranges of $\mathrm{Pb}, \mathrm{Sb}$ and As were 93.7-99.3\%, 1.5-6.3\%, and 0.21-0.97\%, respectively, in the elemental composition among five commercial shot pellet samples. These observations imply that mongooses inhabiting the Ukumehame military firing range have been exposed to $\mathrm{As}, \mathrm{Sb}$, and $\mathrm{Pb}$ derived from the shot pellet in the field.

In the previous study by Andrade et al. (2013), $\mathrm{Pb}$ concentrations in the brain of rats administrated a mixture of $\mathrm{Pb}$ and As, were significantly higher than those in ones which were exposed to only $\mathrm{Pb}$. Cobbina et al. (2015) also reported $\mathrm{Pb}$ exposure to binary mixtures induced significant increase in $\mathrm{Pb}$ levels in the brain of mice. Moreover, in their study, brain showed higher $\mathrm{Pb}$ concentrations compared to liver of the mice which were treated with a toxic metal mixture. Considering the above observations, mongooses from the firing range might preferentially accumulate $\mathrm{Pb}$ in the brain. In the present study, it was found that a main organ of $\mathrm{Pb}$ accumulation was brain rather than liver and kidney but the cause is unclear at present. $\mathrm{Pb}$ bioavailability in wildlife is affected by soil characteristics such as redox potential, $\mathrm{pH}$, ionic strength, concentration of reducing agents, presence of reactants (e.g. acids, bases, sulfate, carbonate) and so on (SAAMI, 1996). Furthermore, Jorgensen and Willems (1987) reported that the transformation rate to more soluble $\mathrm{Pb}$ species was markedly reduced when soil $\mathrm{pH}$ and/or organic matter contents were high. Therefore, higher cerebral $\mathrm{Pb}$ concentrations in the small Indian mongooses from the firing range might be derived from various environmental parameters such as soil condition, chemical species, metal levels in background and organisms in its habitat, and other factors.

\section{Conclusions}

The present study showed that environmental bioaccumulation of $\mathrm{Ni}, \mathrm{Cd}$ and $\mathrm{Pb}$ pre-existed in the Hawaiian Islands, especially, $\mathrm{Ni}$ in Oahu, $\mathrm{Pb}$ in Maui, and $\mathrm{Cd}$ in Hawaii island. The median $\mathrm{Pb}$ concentrations in each organ from the Ukumehame military firing range in Maui were highest among all the locations. Especially, the level in the brain was extremely higher than in the liver and kidney. Lead concentrations in the liver, kidney and brain of several mongooses from the firing range exceeded toxic levels. This probably factored into the reduced body weight in the small Indian mongooses from that area. Lead concentrations in subadult and fetus brains of the mongooses were much higher than those in adults. This elevates the need to closely monitor the real health risks of $\mathrm{Pb}$ and other toxic metals on human and wildlife habituating or using habitats on or near firing ranges.

\section{Acknowledgements}

This work was supported by JSPS KAKENHI 15K00555 provided by the Ministry of Education, Culture, Sports, Science and Technology (MEXT), Japan, and also by the Ministry of Education, Culture, Sports, Science and Technology, Japan (MEXT) to a project on Joint Usage/ Research Center - Leading Academia in Marine and Environment Pollution Research (LaMer) in Ehime University.

The primary investigator/author, Sawako Horai of Tottori University, was responsible for the design, conduct and final write-up of the study. Robert Sugihara (co-author) of the US Dept. of Agriculture, National Wildlife Research Center, Hawaii Field Station, assisted in facilitating the collection of mongoose carcasses from the various sites in Hawaii. No financial or other compensation were tendered or received by or from both parties.

\section{Appendix A. Supplementary data}

Supplementary data associated with this article can be found, in the 
online version, at http://dx.doi.org/10.1016/j.ecolind.2018.03.058.

\section{References}

Agusa, T., Yasugi, S., Iida, A., Ikemoto, T., Anan, Y., Kuiken, T., Osterhaus, A.D.M.E., Tanabe, S., Iwata, H., 2011. Accumulation features of trace elements in massstranded harbor seals (Phoca vitulina) in the North Sea coast in 2002: The body distribution and association with growth and nutrition status. Mar. Pollut. Bull. 62, 963-975.

Adham, K.G., Al-Eisa, N.A., Farhood, M.H., 2011. Risk assessment of heavy metal contamination in soil and wild Libyan jird Meriones libycus in Riyadh, Saudi Arabia. J. Environ. Biol. 32, 813-819.

Andrade, V., Mateus, M.L., Batoréu, M.C., Aschner, M., dos Santos, A.P.M., 2013. Urinary delta-ALA: A potential biomarker of exposure and neurotoxic effect in rats co-treated with a mixture of lead, arsenic and manganese. NeuroToxicology 38, 33-41.

Andrews, S., Sutherland, R.A., 2004. Cu, Pb, and Zn contamination in Nuuanu watershed, Oahu, Hawaii. Sci. Total Environ. 324, 173-182.

ATSDR, 2007. Toxicological profile for lead. U.S. Department of Health and Human Services, Public Health Service. Agency for Toxic Substances and Disease Registry.

Barun, A., Hankson, C.C., Campbell, K.J., Simberloff, D., 2011. A review of small Indian mongoose management and eradications on islands. Island Invasives: Eradication and Management. IUCN, Gland.

Burger, J., Gochfeld, M., Rooney, A.A., Orlando, E.F., Woodword, A.R., Guillette Jr., L.J., 2000. Metals and metalloids in tissues of American alligators in three Florida lakes. Arch. Environ. Contam. Toxicol. 38, 501-508.

Cao, Y., Liu, H., Li, Q., Wang, Q., Zhang, W., Chen, Y., Wang, D., Cai, Y., 2013. Effect of lead sulfide nanoparticles exposure on calcium homeostasis in rat hippocampus neurons. J. Inorg. Biochem. 126, 70-75.

Capelli, R., Das, K., De Pellegrini, R., Drave, G., Lepoint, G., Miglio, C., Minganti, V., Poggi, R., 2008. Distribution of trace elements in organs of six species of cetaceans from the Ligurian Sea (Mediterranean), and the relationship with stable carbon and nitrogen ratios. Sci. Total Envrion. 390, 569-578.

Cardellicchio, N., Decataldo, A., Di Leo, A., Giandomenico, S., 2002. Trace elements in organs and tissues of striped dolphins (Stenella coeruleoalba) from the Mediterranean sea (Southern Italy). Chemosphere 49, 85-90.

Cobbina, S.J., Chen, Y., Zhou, Z., Wu, Xueshan, Feng, W., Wang, W., Mao, G., Xu, H., Zhang, Z., Wu, X., Yang, L., 2015. Low concentration toxic metal mixture interactions: Effects on essential and non-essential metals in brain, liver, and kidneys of mice on sub-chronic exposure. Chemosphere 132, 79-86.

Cui, J., Wu, B., Halbrook, R.S., Zang, S., 2013. Age-dependent accumulation of heavy metals in liver, kidney and lung tissues of homing pigeons in Beijing, China. Ecotoxicology 22, 1490-1497.

Damek-Poprawa, M., Sawicka-Kapusta, K., 2003. Damage to the liver, kidney and testis with reference to burden of heavy metals in yellow-necked mice from areas around steelworks and zinc smelters in Poland. Toxicology 186, 1-10.

De Carlo, E.H., Tomlinson, M.S., Anthony, S.S., 2005. Trace elements in streamed sediments of small subtropical streams on O'ahu, Hawai'i: Results from the USGS NAWQA program. Appl. Geochem. 20, 2157-2188.

De Carlo, E.H., Anthony, S.S., 2002. Spatial and temporal variability of trace element concentrations in an urban subtropical watershed, Honolulu, Hawaii. Appl. Geochem. 17, 475-492.

Dewanjee, S., Sahu, R., Karmakar, S., Gangopadhyay, M., 2013. Toxic effects of lead exposure in Wister rats: Involvement of oxidative stress and the benefical role of edible jute (Corchorus olitorius) leaves. Food Chem. Toxicol. 55, 78-91.

DOH HEER (Hawai'i Department of Health Hazard Evaluation and Emergency Response), 2012. Hawaiian Islands soil metal background evaluation report. pp. 37.

Fritsch, C., Cosson, R.P., Cœurdassier, M., Raoul, F., Giraudoux, P., Crini, N., de Vaufleury, A., Scheifler, R., 2010. Responses of wild small mammals to pollution gradient: Host factors influence metal and metallothionein levels. Environ. Pollut. $158,827-840$.

Fukasawa, K., Hashimoto, T., Tatara, M., Abe, S., 2013. Reconstruction and prediction of invasive mongoose population dynamics from history of introduction and management: a Bayesian state-space modelling approach. J. Appl. Ecol. 50, 469-478.

Gilchrist, J.S., Jennings, A.P., Veron, G., Cavallini, P., 2009. Family Herpestisdae (mongooses). In: Wilson D.E., Mittermeier, R.A. (eds.), Handbook of the Mammals of the World. vol. 1. Carnivores, pp. 262-328., Lynx Ed., Barcelona.

Goyer, R.A., Leonard, D.L., Moore, J.F., Rhyne, B., Krigman, M., 1970. Lead dosage and the role of the intranuclear inclusion body. Arch. Environ. Health 20, 705-711.

Grandjean, P., Landrigan, P.J., 2007. Developmental neurotoxicity of industrial chemicals -authors' reply. Lancet 369, 821-822.

Hédouin, L., Metian, M., Gates, R.D., 2011. Ecotoxicologycal approach for assessing the contamination of a Hawaiian coral reef ecosystem (Honolua Bay, Maui) by metals and a metalloid. Marine Environ. Res. 71, 149-156.

Hédouin, L., Reichelt-Brushett, A.J., Gates, R.D., 2009. Assessment of metals and a metalloid in sediments from Hawaiian coral ref ecosystems. Marine Pollut. Bull. 58, 1739-1765.

Horai, S., Minagawa, M., Ozaki, H., Watanabe, I., Takeda, Y., Yamada, K., Ando, T., Akiba, S., Abe, S., Kuno, K., 2006. Accumulation of $\mathrm{Hg}$ and other heavy metals in the Javan mongoose (Herpestes javanicus) captured on Amamioshima Island, Japan. Chemosphere 65, 657-665.

Horai, S., Watanabe, I., Takada, H., Iwamizu, Y., Hayashi, T., Tanabe, S., Kuno, K., 2007. Trace element accumulations in 13 avian species collected from the Kanto area, Japan. Sci. Total Envrion. 373, 512-525.

Jogensen, S.S., Willems, M., 1987. The fate of lead in soils: the transformation of lead pellets in shooting-range soils. Ambo 16, 11-15.
Kalisinska, E., Lanocha-Arendarczyk, N., Kosik-Bogacka, D., Budis, H., Podlasinska, J., Popiolek, M., Pirog, A., Jedrzejewska, A., 2016. Brains of native and alien mesocarnivores in biomonitoring of toxic metals in Europe. Plos One. http://dx.doi.org/ 10.1371/journal.pone.0159935.

Krachler, M., Emons, H., Zheng, J., 2001. Speciation of antimony for the 21th century: promises and pitfalls. Trends Anal. Chem. 20, 79-90.

Kuwagata, M., Ogawa, T., Shioda, S., Nagata, T., 2009. Evaluation of rat fetal brain after prenatal exposure to valproic acid in a developmental neurotoxicity study. Hatano kenkyujo nenpo 32, 14-21 (in Japanese).

Lahaye, V., Bustamante, P., Dabin, W., Churlaud, C., Caurant, F., 2007. Trace element levels in foetus-mother pairs of short-beaked common dolphins (Delphinus delphis) stranded along the French coasts. Environ. Int. 33, 1021-1028.

Lazarus, M., Sekica, A., Orct, T., Reljić, S., Kusak, J., Jurasović, J., Huber, Đ., 2017. Apex predatory mammals as bioindicator species in environmental monitoring of elements in Dinaric Alps (Croatia). Environ. Sci. Pollut. Res. 24, 23977-23991.

Lewis, L.A., Poppenga, R.J., Davidson, W.R., Fischer, J.R., Morgan, K.A., 2001. Lead toxicosis and trace element levels in wild birds and mammals at a firearms training facility. Arch. Environ. Contam. Toxicol. 41, 208-214.

Lowe, S., Browne, M., Boudjelas, S., De Poorter, M., 2000. 100 of the world's worst invasive alien species a selection from the global invasive species database. Published by The Invasive Species Survival Commission (SSC) of the World Conservation Union (IUCN), pp. 12.

Ma, W.C., 1989. Effect of soil pollution with metallic lead pellets on lead bioaccumulation and organ/body weight alterations in small mammals. Arch. Environ. Contam. Toxicol. 18, 617-622.

Ma, W.C., 1996. Lead in mammals. Pp. 281-296 in In: Beyer, W.N., Heinz, G., Redmon Norwood, A.W. (Eds.), Environmental Contaminants in Wildlife, Interpreting Tissue Concentrations. Lewis Publishers, Boca Raton, Fl., USA, pp. 494.

Mahfouz, C., Henry, F., Courcot, L., Pezeril, S., Bouveroux, T., Dabin, W., Jauniaux, T., Khalaf, G., Amera, R., 2014. Harbour porpoises (Phocoena phocoena) stranded along the southern North Sea: an assessment through metalic contamination. Environ. Res. 133, 266-273.

Mailman, R.B., 1980. Heavy metals. In: Pretty, J.J. (Ed.), Introduction to Environmental Toxicology. Elsevier, New York, N.Y., pp. 34-43.

Mansouri, M.T., Naghizadeh, B., López-Larrubia, P., Cauli, O., 2012. Gender-dependent behavioural impairment and brain metabolites in young adult rats after short term exposure to lead acetate. Toxicol. Lett. 210, 15-23.

McMurtry, G.M., Wiltshire, J.C., Kauahikaua, J.P., 1995. Heavy metal anomalies in coastal sediments of O'ahu, Hawai'i. Pacific Sci. 49, 452-470.

Nam, D.H., Anan, Y., Ikemoto, T., Okabe, Y., Kim, E.Y., Subramanian, A., Saeki, K., Tanabe, S., 2005. Specific accumulation of 20 trace elements in grate cormorants (Phalacrocorax carbo) from Japan. Envrion. Pollut. 134, 503-514.

Reed, L.A., McFee, W.E., Pennington, P.L., Wirth, E.F., Fulton, M.H., 2015. A survey of trace element distribution in tissues of the dwarf sperm whale (Kogia sima) stranded along the South Carolina coast from 1990-2011.

Romero, M., Polizzi, P., Chiodi, L., Robles, A., Das, K., Gerpe, M., 2017. Metals as chemical tracers to discriminate ecological populations of threatened Franciscana dolphins (Pontoporia blainvillei) from Argentina. Environ. Sci. Pollut. Res. 24 3940-3950.

Rossipal, E., Krachler, M., Li, F., Micetic-Turk, D., 2000. Investigation of the transport of trace elements across barriers in humans: studies of placental and mammary transfer. Acta Pædiatr. 89, 1190-1195.

SAAMI (Sports Arms and Ammunition Manufacture's Institute), 1996. Lead Mobility at Shooting Ranges. Facility Development series Sports Arms and Ammunition Manufacturing Institute, Newtown, CT.

Schmitt, C.J., Brumbaugh, W.G., 1990. National contaminant biomonitoring program: Concentrations of arsenic, cadmium, copper, lead, mercury, selenium, and zinc in U.S. freshwater fish. Arch. Environ. Contam. Toxicol. 19, 731-747.

Stansley, W., Roscoe, D.E., 1996. The uptake and effects of lead in small mammals and frogs at a trap and skeet range. Arch. Environ. Contam. Toxicol. 30, 220-226.

Sutherland, R.A., Tolosa, C.A., 2000. Multi-element analysis of road-deposited sediment in an urban drainage basin, Honolulu. Hawaii. Environ. Pollut. 110, 483-495.

Sutherland, R.A., Tack, F.M.G., Tolosa, C.A., Verloo, M.G., 2001. Metal extraction from road sediment using different strength reagents: impact on anthropogenic contaminant signals. Environ. Monit. Assess. 71, 221-242.

Takamatsu, T., Murata, T., Koshikawa, M.K., Watanabe, M., 2010. Weathering and dissolution rates among $\mathrm{Pb}$ shot pellets of differing elemental compositions exposed to various aqueous and soil conditions. Arch. Environ. Contam. Toxicol. 59, 91-99.

Underwood, E.J., 1975. Trace Elements in Human and Animal Nutrition, third ed. Academic Pr., NY, pp. 545.

Underwood, E.J., 1977. Trace Elements in Human and Animal Nutrition, fourth ed. Academic Pr., NY, pp. 545.

Wada, O., 1985. Kinzoku to hito. - ecotoxicology to rinsho-. Tokyo. pp. 320 (in Japanese).

Watanabe, I., Horai, S., Ogawa, D., Nakajima, S., Funakoshi, K., Hirano, K., Ogura, G., 2010. Trace element accumulations in Indian mongoose Herpestes auropunctatus collected from southern part of Onna Village, Okinawa Prefecture and mainland Kyusyu, Kagoshima Prefecture. People Environ. 36, 209-220 (in Japanese).

Watanabe, I., Kunito, T., Tanabe, S., Amano, M., Koyama, Y., Miyazaki, N., Petrov, E.A., Tatsukawa, R., 2002. Accumulation of heavy metals in Caspian seals (Phoca caspica). Arch. Envrion. Contam. Toxicol. 43, 109-120.

Watanabe, I., Ishihashi, H., Tanabe, S., Amano, M., Miyazaki, N., Petrov, E.A., Tatsukawa, R., 1996. Trace element accumulation in Baikal seal (Phoca sibirica) from the Lake Baikal. Envrion. Pollut. 94, 169-179.

Watari, Y., Nagata, J., Funakoshi, K., 2011. New detection of a 30-year-old population of introduced mongoose Herpestes auropunctatus on Kyushu Island, Japan. Biol. Invasions 13, 269-276. 
Woods, C.A., Sergile, F.E., 2001. Biogeography of the West Indies Patterns and Perspectives, second ed. CRC Press, Florida, USA 414-418 in pp. 579.

Yamada, F., Ogura, G., Abe, S., 2015. Herpestes auropunctatus (Hodgson, 1836). In: Ohdachi, S.D., Ishibashi, Y., Iwasa, M.A., Fukui, D., Saitoh, T. (Eds.), The Wild Mammals of Japan, 2nd ed. Shoukadoh Book Sellers, Kyoto, pp. 272-274 (in Japanese).
Yanai, H., 2011. Statcel-The useful Addin Forms on Excel, third ed., Seiunsya, Tokyo, pp. 294 (in Japanese)

Zaccaroni, A., Niccoli, C., Andreani, G., Scaravelli, D., Ferrante, M.C., Lucisano, A., Isani, G., 2011. Trace metal concentration in wild avian species from Camania, Italy. Cent. Eur. J. Chem. 9, 86-93. 